Acta Universitatis Wratislaviensis No 3705

PRAWO CCCXX

Wrocław 2016

DOI: $10.19195 / 0524-4544.320 .1$

\author{
JOLANTA BEHR \\ Uniwersytet Wrocławski \\ e-mail: jolantasikora28@gmail.com
}

\title{
Samorządność gminna i jej gwarancje w Rzeczypospolitej Polskiej i w kraju związkowym Brandenburgia
}

\section{Wstęp}

Gmina jest podstawową jednostką samorządu terytorialnego. Stanowi część administracji publicznej funkcjonującej na zasadzie decentralizacji ${ }^{1}$. W konsekwencji ,posiada ona uprawnienie do samodzielnego podejmowania wiążących decyzji" "2 dotyczących jej działalności, której celem jest zaspokajanie potrzeb wspólnoty samorządowej (art. 166 Konstytucji RP). Gmina w przedstawionym ujęciu stanowi istotną część administracji publicznej ${ }^{3}$. Jej konstrukcję prawną tworzy się najczęściej w oparciu o pojęcie samorządności, które najpełniej oddaje jej istotę 4 .

Przedmiotem niniejszego opracowania jest analiza samorządności gminnej oraz jej gwarancji w Rzeczypospolitej Polskiej i Republice Federalnej Niemiec. Ze względu na występowanie odmiennych rozwiązań prawnych w poszczegól-

1 W. Miemiec, M. Miemiec, Reformowanie administracji publicznej, [w:] Między tradycja a przyszłościa w nauce prawa administracyjnego. Księga jubileuszowa dedykowana Profesorowi Janowi Bociowi, red. J. Supernat, Wrocław 2009, s. 485, www.wuwr.com.pl/onlinetexts/download/37. html (dostęp: 3.09.2016).

2 J.C.N. Raadschelders, Centralizacja i decentralizacja: dychotomia i kontinuum, „Samorząd Terytorialny" 1994, nr 6, s. 4.

3 M. Miemiec, Gmina w systemie administracji publicznej Republiki Federalnej Niemiec, Wrocław 2007, s. 9.

${ }^{4}$ C. Brüning, Kommunalrecht, [w:] Besonderes Verwaltungsrecht, t. 3, Kommunalrecht, Haushalts- und Abgabenrecht, Ordnungsrecht, Sozialrecht, Bildungsrecht, Recht des öffentlichen Dienstes, red. D. Ehlers, M. Fehling, H. Pünder, wyd. 3, Heidelberg 2013, s. 5. 
nych krajach związkowych Republiki Federalnej Niemiec poddano analizie wyłącznie porządek prawny kraju związkowego Brandenburgia.

Dla osiągnięcia celu badawczego zastosowano metodę językowo-logiczną polegającą na dokonywaniu analizy i wykładni tekstów aktów prawnych. Treść norm prawnych ustalono również w oparciu o dorobek przedstawicieli nauki prawa oraz orzecznictwo sądów krajowych. Ze względu na przedmiot opracowania zastosowano metodę komparatystyki prawniczej polegającą na porównywaniu konstrukcji i funkcjonowania określonych instytucji w omawianych porządkach prawnych.

\section{Pojęcie samorządności}

W żadnym $\mathrm{z}$ obu analizowanych ustawodawstw nie wypracowano definicji legalnej pojęcia samorządności. Podejmowano liczne próby jej konstruowania. Najczęściej następowało to poprzez wskazanie jej elementów składowych. Podkreśla się, że warunkiem koniecznym samorządności jest „zdolność do samodzielnego zarządzania swoimi sprawami we własnym imieniu i na własną odpowiedzialność"5. Podobna interpretacja występuje na gruncie języka potocznego, w którym słowo „samorządny” oznacza samodzielnie kierującego swoją działalnością ${ }^{6}$.

Odnosząc się do powyższego, należy stwierdzić, że „samodzielność” jest pojęciem umożliwiającym zrozumienie istoty samorządności. Wyrażenie to nie jest jednak jednoznaczne. Przyrównuje się je do pojęcia „wolności”, które mimo licznych prób zdefiniowania wciąż jest niejasne ${ }^{7}$. Zdaniem J. Panejki samodzielność to brak podległości służbowej centralnemu rządowi. W celu zobrazowania tego zjawiska porównał je do działalności sądów, które mimo istnienia wyższej instancji załatwiają swe sprawy samodzielnie ${ }^{8}$. Twierdził, że samodzielność stanowi istotę decentralizacji administracji państwowej.

Decentralizacja definiowana jest natomiast jako jeden ze sposobów organizacji aparatu państwowego. Cechuje ją zapewnienie względnej samodzielności poszczególnym jednostkom terytorialnym. Jest to możliwe między innymi dzięki przyznaniu im osobowości prawnej odrębnej od organów państwowych ${ }^{9}$. Należy

5 M. Mączyński, Samodzielność a samorzadność, [w:] Nadzór nad samorządem a granice jego samodzielności, red. M. Stec, M. Mączyński, Warszawa 2011, s. 16.

6 Definicja wg słownika PWN: www.sjp.pwn.pl/slownik/2519152 (dostęp: 3.09.2016).

7 W. Kisiel, [w:] Komentarz do ustawy o samorzadzie gminnym, red. P. Chmielnicki, wyd. 3, Warszawa 2007, s. 56.

8 J. Panejko, Geneza i podstawy samorządu europejskiego, Paryż 1926 (reprint Warszawa 1990), s. 96.

9 E. Iserzon, Prawo administracyjne. Podstawowe instytucje, Warszawa 1968, s. 91. 
mieć jednak na uwadze, że wspomniana samodzielność jest ograniczona. Przyjęcie odmiennego założenia prowadziłoby do układu, w którym poszczególne publiczne jednostki administrujące posiadałyby pełną autonomię, a tak w istocie nie jest ${ }^{10}$. Innymi słowy, decentralizacja to taki system administracji, w którym podmioty administrujące posiadają samodzielność względem władzy centralnej ${ }^{11}$. Aby owa samodzielność nie stała się jedynie iluzoryczna, stworzono gwarancje zapobiegające ingerowaniu $\mathrm{w}$ jej istotę. Wszelkie działania mające na celu jej ograniczenie, aby były legalne, winny mieć umocowanie ustawowe i przybierać określone ustawowo formy ${ }^{12}$.

W niemieckiej literaturze przedmiotu dla określenia pojęcia samorządności stosuje się wyrażenie „Selbstverwaltung” (,selbst” — samo, „verwalten” - administrowanie, zarząd). Jest ono pojmowane podobnie jak w polskim piśmiennictwie. Prócz tego wskazuje się, że „samorządność gmin urzeczywistnia etyczną i polityczną zasadę. Pierwsza z nich jest absolutną, ostatnia relatywną" 13 . Prezentowany jest również pogląd, w myśl którego „samorządność gminna jest pośrednią władzą państwową, wykonywaniem przydzielonych funkcji władzy państwowej [...], która jest ograniczona przez ustawy federalne i ustawy krajów związkowych"14. Powszechnie podzielaną opinią jest podwójne znaczenie pojęcia samorządności gminnej - polityczne i prawne. Pierwsze z nich przesądza o polityczno-administracyjnej decentralizacji, drugie stanowi natomiast konstytucyjnoprawną zasadę budowy państwa ${ }^{15}$. W literaturze niemieckiej nie budzi obecnie wątpliwości, że samorządność gminna jest zasadą organizacyjną (kommunale Selbstverwaltung als Organisationsprinzip $)^{16}$.

Dla potrzeb niniejszych rozważań przez samorządność gminną będę natomiast rozumieć wyznaczoną zakresem gwarancji prawnych możliwość samodzielnego zarządzania, a więc kształtowania wewnętrznych struktur i podejmowania określonych prawem działań w imieniu własnym i na własną odpowiedzialność. Działań celowych, zmierzających do realizacji określonych prawem zadań.

Większą wagę niż do konstruowania definicji przywiązuje się jednak do precyzyjnego określenia gwarancji prawnych samorządności. To one, wespół z nadzorem, zakreślają jej granice. Dlatego też częstym sposobem charakteryzowania pojęcia samorządności jest analizowanie go w kontekście gwarancji zapewniających jej urzeczywistnienie. Pod rozwagę bierze się nadto władztwa przyznane

10 J. Zimmermann, Prawo administracyjne, wyd. 5, Warszawa 2012, s. 188.

11 T. Bigo, Zwiazki publiczno-prawne w świetle ustawodawstwa polskiego, Warszawa 1928, s. 122.

12 Prawo administracyjne, red. M. Wierzbowski, wyd. 11, Warszawa 2013, s. 221.

13 H. Peters, Lehrbuch der Verwaltung, Berlin 1949, s. 287.

14 M. Staak, [w:] Die Zukunft der kommunalen Selbstverwaltung: Vorträge und Diskussionsbeiträge der 58. Staatswissenschaftlichen Fortbildungstagung 1990 der Hochschule für Verwaltungswissenschaften Speyer, red. W. Blümel, H. Hill, Berlin 1991, s. 73.

15 M. Nierhaus, [w:] Kommunale Selbstverwaltung. Beiträge zur Debatte, red. C. Büchner, J. Franzke, Berlin 1999, s. 8.

16 Ibidem, s. 51. 
gminie (obszary, w obrębie których gmina samodzielnie realizuje swoje uprawnienia), gdyż przekazanie zadań i władztwa stanowi cechę decentralizacji ${ }^{17}$.

\section{Podstawy prawne - Europejska Karta Samorządu Lokalnego}

Omawiane porządki prawne posiadają wspólną podstawę prawną samorządności gminnej. Jest nią Europejska Karta Samorządu Lokalnego ${ }^{18}$. Jej postanowienia zakreślają granice, w obrębie których winny być kształtowane modele samorządu lokalnego w państwach będacych stronami umowy ${ }^{19}$. W preambule aktu potwierdzono prawo do szerokiej samorządności (autonomy) ${ }^{20}$. Pojęcie to odnosi się do kompetencji, metod i środków umożliwiających jej realizację. Niemniej, również ten akt nie zawiera definicji legalnej pojęcia samorządności. W oparciu o jego postanowienia możliwe jest jednak wskazanie obszarów, w obrębie których powinna być ona realizowana. Artykuł 4 Karty stanowi o swobodzie, którą posiadają wspólnoty lokalne w każdej sprawie nie wyłączonej z ich kompetencji lub nie wchodzącej w zakres kompetencji innych organów władzy. Zawiera ponadto wytyczne służące prawidłowemu powierzaniu kompetencji przez organy władzy centralnej lub regionalnej. Owo powierzenie powinno być pełne i całkowite. Ich ograniczanie bądź kwestionowanie może następować wyłącznie w granicach prawa.

Kolejnym elementem zapewniającym samorządność jest uprawnienie wspólnot lokalnych do samookreślenia ich wewnętrznych struktur administracyjnych. Umożliwia to odpowiednie przystosowanie do zaspokajania specyficznych potrzeb danej wspólnoty w celu skutecznego nią zarządzania (art. 6 ust. 1). Karta stanowi także o prawie do posiadania odpowiednich zasobów finansowych, które powinny być zapewnione wspólnotom do realizacji ich zadań (art. 9). Wprowadza również możliwość odwołania do sądu w celu swobodnego sprawowania swych uprawnień i poszanowania zasad samorządu lokalnego (art. 11).

Dla podkreślenia doniosłości powyższych postanowień art. 2 Karty stanowi, że zasada samorządu lokalnego powinna być uznana przez prawo krajowe i, jeśli to możliwe, również przez konstytucję. Postanowienie to zostało zrealizowane w obu omawianych porządkach prawnych. Zasadę samorządności gmin zapewniono w aktach prawnych zajmujących najwyższe miejsce w hierarchii źródeł pra-

17 Prawo administracyjne, red. M. Wierzbowski, wyd. 10, Warszawa 2011, s. 245.

18 Europejska Karta Samorządu Lokalnego z dnia 15 października 1985 r., Dz.U. z 1994 r. Nr 124, poz. 607 ze zm.

19 Z. Leoński, Samorzad terytorialny w RP, Warszawa 1998, s. 21.

${ }^{20}$ W przekładzie na język niemiecki zostało użyte wyrażenie „Selbständigkeit” oznaczające samodzielność. 
wa. Są nimi: Konstytucja Rzeczypospolitej Polskiej z dnia 2 kwietnia 1997 r. ${ }^{21}$, Ustawa Zasadnicza Republiki Federalnej Niemiec z dnia 23 maja 1949 r. ${ }^{22}$ oraz Konstytucja Kraju Związkowego Brandenburgia z dnia 20 sierpnia 1992 r. ${ }^{23}$. Zasada ta jest ponadto wyinterpretowywana $\mathrm{z}$ postanowień polskiej ustawy z dnia 8 marca 1990 r. o samorządzie gminnym ${ }^{24}$ oraz Konstytucji Gminnej Kraju Związkowego Brandenburgia z dnia 18 grudnia 2007 r. $^{25}$

\section{Gwarancje samorządności}

Wprowadzenie do porządku prawnego określonej zasady bez jednoczesnego zapewnienia instrumentów prawnych umożliwiających skuteczne egzekwowanie jej realizacji, stanowiłoby jedynie niezobowiązującą deklarację ustawodawcy. Dlatego też w demokratycznym państwie prawnym konieczne jest wyposażenie gmin w środki prawne, które zapewnią ochronę przed nadmierną ingerencją podmiotów trzecich w ich samorządność. Dla potrzeb niniejszego opracowania przez gwarancje samorządności należy rozumieć wszelkie instytucje oraz środki prawne, które zapewniają faktyczną realizację zasady samorządności.

Odnosząc się do przedmiotu ochrony, należy podkreślić, że w niemieckim porządku prawnym ochronie podlega samorządność gmin (art. 28 GG, art. 97 BbgVerf). W polskim prawie przedmiot ochrony stanowi natomiast samodzielność gmin (art. 165 ust. 2 Konstytucji RP). W literaturze przedmiotu podkreśla się jednak, że istotą samorządu, jako odrębnego podmiotu publicznego w państwie jest jego samodzielność ${ }^{26}$. Mając na uwadze powyższe, należy więc stwierdzić, że istotny zakres ochrony w omawianych państwach jest tożsamy.

\subsection{Rzeczpospolita Polska}

Jak wykazano powyżej, przedmiotem ochrony prawnej w polskim ustawodawstwie jest samodzielność gmin. Jej źródłem jest prawo powszechnie obowią-

21 Dz.U. Nr 78, poz. 483 ze zm., dalej: „Konstytucja RP”.

22 Grundgesetz für die Bundesrepublik Deutschland vom. 23 Mai 1949 (BGBl. S. 1), zuletzt geändert durch das Gesetz vom 11. Juli 2012 (BGB1. I S. 1478); dalej: „GG”.

23 Verfassung des Landes Brandenburg vom 20. August 1992 (GVBl. I/92, [Nr. 18], s. 298), zuletzt geändert durch Gesetz vom 05. Dezember 2013 (GVBl. I/13, [Nr. 42]); dalej: „BbgVerf”.

24 Tekst jedn. Dz.U. z 2016 r., poz. 446.

25 Kommunalverfassung des Landes Brandenburg vom 18. Dezember 2007 (GVBl. I/07, [Nr. 19], s. 286), zuletzt geändert durch Artikel 4 des Gesetzes vom 10. Juli 2014 (GVBl. I/14, [Nr. 32]); dalej: „BbgKVerf”.

26 Zob. J. Jagoda, Sadowa ochrona samodzielności jednostek samorzadu terytorialnego, Warszawa 2011, s. 27 n. 
zujące ${ }^{27}$. Wśród poglądów przedstawicieli nauki prawa na temat samodzielności gmin można wyodrębnić dwa dominujące nurty. Pierwszy z nich nie wprowadza konstrukcji pojęciowej „gwarancji samodzielności gminnej”. Uznaje poszczególne instytucje prawne, takie jak osobowość prawną gminy, samodzielność finansową czy swobodę w zakresie określania wewnętrznego ustroju wyłącznie za prawne determinanty samodzielności ${ }^{28}$. Drugi natomiast, charakteryzując samodzielność gminną, czyni to poprzez pryzmat gwarancji samodzielności gminnej, opisując jej poszczególne elementy. B. Dolnicki ${ }^{29}$ tworzy ich ogólny zbiór, nie wprowadzając przy tym wewnętrznego podziału. W ten sposób czyni również E. Ochendowski ${ }^{30}$. W. Miemiec i M. Miemiec wskazują natomiast na istnienie klasyfikacji gwarancji samodzielności opartej na charakterze źródeł prawa, które zabezpieczają samodzielność prawną samorządu terytorialnego. Zaznaczają, że w jej obrębie występuje dychotomiczny podział na gwarancje zewnętrzne i wewnętrzne. Podstawę normatywną gwarancji zewnętrznych stanowią akty prawa międzynarodowego i ponadnarodowego. Gwarancje wewnętrzne mają natomiast źródło w prawie krajowym — konstytucji i ustawach ${ }^{31}$.

W celu usystematyzowania wyróżnionych w literaturze gwarancji samodzielności gmin celowe jest dokonanie ich wewnętrznego podziału na następujące rodzaje: instytucjonalne, ustrojowe oraz finansowe. Przyporządkowanie gwarancji do określonego rodzaju jest uzależnione od wykazywanych przez nią cech charakterystycznych.

Gwarancje instytucjonalne zapewniają istnienie gminy jako odrębnej jednostki składowej systemu administracji. Determinują jej kształt, umożliwiając uczestniczenie w obrocie prawnym. Statuują gminę jednostką odrębną i niezależną od innych podmiotów. Konsekwencją powyższego jest zdolność do samodzielnego wykonywania zadań. Gwarancje ustrojowe zapewniają natomiast swobodę w zakresie określenia organizacji wewnętrznej. Dzięki nim gmina może więc swobodnie, w granicach prawa, określić ustrój wewnętrzny, a także tworzyć jednostki pomocnicze. Gwarancje finansowe zapewniają z kolei posiadanie odpowiednich zasobów finansowych przez gminę. Umożliwiają także samodzielne gospodarowanie kapitałem ${ }^{32}$. Brak tej gwarancji czyniłby bowiem gminę jednostką słabą,

27 A. Błaś, Konstrukcja prawna samodzielności jednostki samorzadu terytorialnego, [w:] Granice samodzielności wspólnot samorządowych: Międzynarodowa Konferencja Naukowa, Baranów Sandomierski, 22-25 maja 2005, red. E. Ura, Rzeszów 2005, s. 18-27.

28 E. Ura, E. Ura, Prawo administracyjne, Warszawa 2009, s. 176; Prawo administracyjne, red. M. Wierzbowski, wyd. 10, Warszawa 2011, s. 246; J. Zimmermann, Prawo administracyjne, wyd. 4, Warszawa 2010, s. 176-179.

29 B. Dolnicki, Samorzad terytorialny, wyd. 5, Warszawa 2012, s. 56-57.

30 E. Ochendowski, Prawo administracyjne. Część ogólna, Torun 2004, s. 326-327.

31 W. Miemiec, M. Miemiec, Konstytucyjne gwarancje samodzielności samorzadu terytorialnego, „Przegląd Prawa i Administracji” 38, Wrocław 1997, s. 152 n. („Acta Universitatis Wratislaviensis" No 2018).

32 W tym kontekście wyrażenie „kapitał” interpretowane jest wąsko, jako jedna z jego form, tj. finansowa. 
która ze względu na brak wymaganych środków jest niezdolna do realizacji zadań. Wymienione wyżej gwarancje, mimo ich teoretycznego oddzielenia, są jednak ze sobą ściśle powiązane. Każda z nich zabezpiecza bowiem gminę przed nieuprawnioną ingerencją w jej działania przez podmioty zewnętrzne.

\subsubsection{Gwarancje instytucjonalne}

Instytucjonalne gwarancje samodzielności gminy zapewniają istnienie gminy jako odrębnego podmiotu w strukturze państwa. Artykuł 164 Konstytucji RP stanowi, że gmina jest podstawową jednostką samorządu terytorialnego. Ustrojodawca, wprowadzając instytucję gminy, określił jednocześnie jej pozycję prawną. Gmina jako jedyna jednostka samorządu terytorialnego została wyrażona expressis verbis w Konstytucji RP. Wyróżnia ją to spośród pozostałych jednostek samorządu terytorialnego. Należy zaznaczyć, że ustrojodawca zapewnił istnienie gminy jako elementu w strukturze, a nie istnienie poszczególnych jednostek gminnych. Mogą one bowiem ulegać przekształceniu bądź zniesieniu w drodze rozporządzenia Rady Ministrów, wydanego na podstawie art. 4 u.s.g.

Konsekwencję wyodrębnienia gminy w strukturze administracji publicznej stanowi przyznanie jej osobowości prawnej. Artykuł 165 ust. 1 Konstytucji RP stwierdza wprost, że jednostki samorządu terytorialnego posiadają osobowość prawną. W odniesieniu do gminy zostało to wyrażone w art. 2 ust. 2 u.s.g. Nadal nie jest jasny charakter prawny tej osobowości: publicznoprawny, prywatnoprawny czy też jest to podwójna osobowość prawna ${ }^{33}$. Owo nieprecyzyjne uregulowanie już od wielu lat stanowi przedmiot krytyki w nauce prawa ${ }^{34}$. T. Bigo twierdzi, że osobowość prawna jest jedna na całym obszarze prawa, a pojęciowe wyodrębnienie tzw. osobowości publiczno-prawnej jest metodą fałszywą ${ }^{35}$. Zdanie to podziela A. Agopszowicz, który podkreśla ponadto, że „osobowość prawna jest instytucją wspólną zarówno prawu administracyjnemu, jak i prawu cywilnemu"36. Stanowisko nauki prawa w tej kwestii nie jest jednak jednolite. Coraz częściej wyrażanym poglądem jest istnienie dualizmu w zakresie osobowości gminy. Wiąże się to z publicznoprawną i prywatnoprawną sferą.

W odniesieniu do charakteru prywatnoprawnego osobowości prawnej decydujące są postanowienia ustawy z dnia 23 kwietnia 1964 r. - Kodeks cywilny ${ }^{37}$. Nie budzą one wątpliwości interpretacyjnych. Artykuł 33 k.c. stanowi, że osobami prawnymi są Skarb Państwa i jednostki organizacyjne, którym przepisy

33 L. Rajca, Konstrukcja osobowości prawnej samorządu terytorialnego, „Samorząd Terytorialny" $2004, \mathrm{nr} 3$, s. 5.

34 W. Miemiec, M. Miemiec, Podmiotowość publicznoprawna gminy, „Samorząd Terytorialny" 1991, nr 11-12, s. 15-19; T. Milczarek, Samorzad gminny, Warszawa 1999, s. 18.

35 T. Bigo, op. cit., s. 27.

36 A. Agopszowicz, Własność komunalna - publiczna czy prywatna?, „Samorząd Terytorialny" 1991, nr 11-12, s. 85 .

37 Tekst jedn. Dz.U. z 2016 r., poz. 380 ze zm., dalej: k.c. 
szczególne przyznają osobowość prawną. Przepisem takim jest niewątpliwie art. 2 ust. 2 u.s.g., który stanowi, że gmina posiada osobowość prawną. Postanowienia te potwierdzają tezę dotyczącą charakteru prywatnoprawnego osobowości prawnej gminy.

Istotą osobowości publicznoprawnej gminy jest natomiast samodzielność w wykonywaniu zadań. Konstruuje się ją w oparciu o postanowienia art. 16 ust. 2 Konstytucji RP. Stanowi on, że samorząd terytorialny uczestniczy w sprawowaniu władzy publicznej. Przysługującą mu w ramach ustaw istotną część zadań publicznych samorząd wykonuje w imieniu własnym i na własną odpowiedzialność. Artykuł 164 ust. 3 Konstytucji RP wprowadza natomiast domniemanie właściwości na rzecz gmin. Zgodnie z nim gmina wykonuje wszystkie zadania samorządu terytorialnego, które nie zostały zastrzeżone dla innych jednostek samorządu terytorialnego. Gmina wykonuje je w imieniu własnym i na własną odpowiedzialność (art. 2 ust. 1 u.s.g.). Powyższe postanowienia potwierdzają istnienie także publicznoprawnej osobowości gminy, która nie została jednak wyrażona wprost w przepisach prawnych.

Elementem zarówno publiczno- jak i prywatnoprawnym, który umożliwia gminie występowanie w obrocie prawnym, jest mienie komunalne ${ }^{38}$. Wykazuje ono dualistyczną naturę: instytucjonalno-prawną oraz finansową. Jest ono gwarancją instytucjonalną, bowiem umożliwia gminie faktyczną realizację jej zadań. Wykazuje także ścisłe powiązania ze sferą finansową. Dlatego też zostanie omówione w ramach gwarancji finansowych.

\subsubsection{Gwarancje ustrojowe}

Gwarancje ustrojowe zapewniają samodzielność w zakresie kształtowania organizacji wewnętrznej jednostek samorządu terytorialnego. Oznacza to istnienie swobody w zakresie decydowania o budowie ustroju wewnętrznego poszczególnych jednostek samorządu terytorialnego, w tym gmin. Artykuł 169 ust. 4 Konstytucji RP stanowi, że ustrój wewnętrzny jednostek samorządu terytorialnego określają, w granicach ustaw, ich organy stanowiące. $\mathrm{O}$ ustroju gminy stanowi jej statut (art. 3 ust. 1 u.s.g.). Jego uchwalenie jest kompetencją rady gminy (art. 18 ust. 2 u.s.g.). Jest to akt prawa miejscowego, powszechnie obowiązujący na terenie gminy ${ }^{39}$. Reguluje m.in.: organizację wewnętrzną oraz tryb pracy rady gminy, listę komisji stałych oraz zasady ich organizacji i funkcjonowania, tryb pracy wójta, a także zasady tworzenia, łączenia, podziału oraz znoszenia jednostek pomocniczych ${ }^{40}$.

O uprawnieniu do tworzenia jednostek pomocniczych mówi expressis verbis art. 5 u.s.g., który stanowi, że gmina może tworzyć jednostki pomocnicze: sołectwa oraz dzielnice, osiedla i inne. Jednostką pomocniczą może być również

38 M. Kuszewska-Gagoś, Podmiotowość publicznoprawna gminy, Lublin 2009, s. 53.

39 W. Kisiel, op. cit., s. 71.

40 Ibidem, s. 59-60. 
położone na terenie gminy miasto. Wprowadzony przez ustawodawcę katalog jednostek pomocniczych gminy jest otwarty. Rada gminy w drodze uchwały stanowi o ich rodzaju. Z powyższego wynika, że mimo powszechnie występującego poglądu, możliwe jest także utworzenie sołectwa w mieście, ale w granicach i na podstawie prawa ${ }^{41}$. Należy mieć na względzie fakt, że owa samodzielność w zakresie kształtowania struktur wewnętrznych gminy nie jest bezwzględna. „Może ona doznać ograniczenia, ale wyłącznie z wyraźnej woli ustawodawcy”42.

\subsubsection{Gwarancje finansowe}

Kolejnym rodzajem gwarancji samodzielności gminy są gwarancje finansowe. Posiadają rozbudowaną wewnętrzną strukturę, co jest wykazywane w licznych opracowaniach naukowych na ten temat ${ }^{43}$. Ich podstawy prawne są zawarte w art. 165 ust. 1 Konstytucji RP. Stanowi on, że jednostkom samorządu terytorialnego przysługuje prawo własności i inne prawa majątkowe. Jest to podstawą prawną posiadanego przez gminę mienia (art. 44 k.c.). Odnosząc się do mienia gmin, należy podkreślić, że samodzielność $\mathrm{w}$ tej sferze nie powinna być utożsamiana ze „swobodnym dysponowaniem mieniem. Samodzielne dysponowanie [...] winno być zawsze realizowane w ramach ustaw" 44 .

Przyznanie gminom mienia nie stanowi jedynego zabezpieczenia ich niezależności finansowej. Zagwarantowano im także odpowiednie środki finansowe służące prawidłowemu wypełnianiu zadań. Gminy posiadają udział w dochodach publicznych. Jego wysokość nie jest kształtowana w sposób dowolny, ale jest odpowiednia do przypadających gminom zadań (art. 167 ust. 1 Konstytucji RP). Dochodami gmin są: dochody własne oraz subwencje ogólne i dotacje celowe z budżetu państwa (art. 167 ust. 2 Konstytucji RP). Poprzez ustawowo zobiektywizowane określenie źródeł dochodów, gminy zostały uniezależnione od arbitralnych decyzji innych organów władzy wpływających na ich gospodarkę finansową (art. 167 ust. 3 Konstytucji RP). Ustawa wyznacza ponadto zakres, w ramach którego gminy mogą samodzielnie określić wysokość podatków i opłat lokalnych na ich obszarze (art. 168 Konstytucji RP).

Zakres gwarancji finansowych jest również uzależniony od możliwości decydowania przez gminę o sposobie wydatkowania posiadanych przez nią środków finansowych. Decyzję w tym zakresie podejmują samodzielnie organy gminy. Nie oznacza to jednak dowolności w zakresie wydatków jednostek samorządu tery-

41 Zob. wyrok Naczelnego Sądu Administracyjnego z dnia 4 lutego 2014 r., II OSK 2910/13.

42 Zob. wyrok Sądu Najwyższego z dnia 7 marca 1996 r., III ARN 56/95.

43 W. Miemiec, [w:] W. Miemiec, K. Sawicka, M. Miemiec, Prawo finansów publicznych sektora samorzadowego, Warszawa 2013, s. 56 n.; E. Kronberger-Sokołowska, Samodzielność finansowa jednostek samorzadu terytorialnego w aktualnym stanie prawnym $w$ Polsce, „Studia Iuridica” 2001, nr 39, s. 99 n.; W. Miemiec, [w:] Prawo finansowe, red. R. Mastalski, E. Fojcik-Mastalska, wyd. 2, Warszawa 2013, s. $431 \mathrm{n}$.

44 Uchwała pełnego składu Sądu Najwyższego z dnia 10 marca 1994 r., III AZP 22/93. 
torialnego, gdyż w tym zakresie stosuje się „ogólne zasady dotyczące wydatków publicznych" 45 .

Ogół opisanych rozwiązań prawnych wpływa na zakres samorządności gmin w Rzeczypospolitej Polskiej. Dla umożliwienia faktycznej realizacji tego prawa Konstytucja RP wprowadza zasadę sądowej ochrony samodzielności jednostek samorządu terytorialnego $^{46}$ (art. 165 ust. 2). Ustawa o samorządzie gminnym odnosi ją bezpośrednio do gmin (art. 2 ust. 3). Oznacza to uprawnienie gminy do „dochodzenia swoich praw przed niezawisłym sądem [...] powszechnym, administracyjnym lub przed Trybunałem Konstytucyjnym"47.

O samodzielności gmin decyduje również nadzór nad ich działalnością. Ze względu na obszerność zagadnienia zostanie ono wyłącznie zasygnalizowane. Należy jednak podkreślić szczególną rolę, jaką w wyznaczaniu granic samodzielności pełni nadzór, bowiem „samodzielności samorządu upatrywać należy nie w fakcie całkowitego jego uniezależnienia się od państwa, ale jasnego, precyzyjnego określenia przypadków, kiedy państwo może wkraczać w sferę działalności samorządu" 48 .

Nadzór nad działalnością gminną uznawany jest „korelatem samorządu, bez którego trudno wyobrazić sobie instytucję samorządu terytorialnego jako elementu państwa"49. A. Wiktorowska uznaje go ,jednocześnie za gwarancję i antygwarancję samodzielności jednostek samorządu terytorialnego; w zależności od obu tych kategorii, tj. nadzoru i samodzielności, jest ona odwrotnie proporcjonalna. Oznacza to, że im bardziej nadzór rozszerza się, tym bardziej samodzielność gminy zawęża się, a im bardziej nadzór zawęża się, tym bardziej samodzielność gminy się rozszerza" ${ }^{50}$.

\subsection{Brandenburgia}

Gwarancje samodzielności gminy w Republice Federalnej Niemiec zostały uregulowane w art. 28 ust. 2 GG. Stanowi on, że gminom musi być zapewnione prawo do regulowania wszystkich spraw wspólnoty lokalnej w ramach ustaw na własną odpowiedzialność. Gwarancja samorządności obejmuje również podsta-

45 E. Malinowska-Misiąg, W. Misiąg, Finanse publiczne w Polsce, wyd. 2, Warszawa 2007, s. 593.

46 Szerzej: B. Adamiak, J. Borkowski, Instytucje prawne sądowej ochrony samodzielności gminy, „Samorząd Terytorialny” 1991, nr 1-2, s. 38-45.

${ }^{47}$ Z. Niewiadomski, Samorząd terytorialny. Ustrój i gospodarka, Bydgoszcz 2011, s. 42.

48 Z. Niewiadomski, [w:] Podmioty administrujace, Warszawa 2011, s. 122. („System Prawa Administracyjnego", red. R. Hauser, Z. Niewiadomski, A. Wróbel, t. 6).

49 B. Dolnicki, Nadzór nad samorządem terytorialnym, Katowice 1993, s. 29.

50 A. Wiktorowska, Prawne determinanty samodzielności gminy. Zagadnienia administracyjnoprawne, Warszawa 2002, s. 193-194. Cyt. za R. Marchaj, Zasada samodzielności, a prawo do prowadzenia wspótpracy przez jednostki samorzadu terytorialnego, [w:] Formy współdziałania jednostek samorzadu terytorialnego, red. B. Dolnicki, Warszawa 2012, s. 458. 
wy własnej odpowiedzialności finansowej gmin. Stanowi je przykładowo należne gminom prawo do pobierania podatków.

Na obszarze Brandenburgii kwestię samorządności gmin regulują postanowienia BbgVerf. Artykuł 97 stanowi, że gminy i związki gmin posiadają prawo do samorządności. Kraj związkowy sprawuje nad nimi wyłącznie nadzór prawny. Gminy i ich związki wypełniają na ich obszarze wszystkie zadania społeczności lokalnej, których na mocy BbgVerf lub ustaw nie zastrzeżono dla innych organów.

Porównując postanowienia GG z rozwiązaniami wprowadzonymi w krajach związkowych, wskazuje się, że art. 28 GG ustanawia minimalny standard (Mindeststandard) samorządności gmin. Regulacje prawne poszczególnych krajów związkowych mogą natomiast zmodyfikować lub rozszerzyć to prawo.

W związku z powyższym należy wziąć pod uwagę sytuację, w której istnieje sprzeczność partykularnego rozwiązania ustawodawstwa kraju związkowego $\mathrm{z}$ art. $28 \mathrm{GG}$. Zgodnie z zasadą prymatu ustawodawstwa federalnego decydujące w tym względzie są wówczas postanowienia GG.

Sytuacja taka istniała podczas dokonywania wykładni językowej normy z art. 97 BbgKVerf. Występującą wówczas sprzeczność norm (Normwiderspruch) rozwiązał Trybunał Konstytucyjny Brandenburgii. Orzekł, że interpretowanie art. 97 tej konstytucji powinno być dokonywane w zgodzie z art. 28 GG. W razie sprzeczności znaczenie priorytetowe należy przyznać postanowieniom $\mathrm{GG}^{51}$.

Samorządność gmin analizuje się jednak najczęściej przez pryzmat przesłanek, które umożliwiają jej realizację. Są nimi gwarancje samorządności. Podkreśla się, że nie posiadają one charakteru prawa podstawowego, co jest im często błędnie przypisywane. Stanowią wyłącznie gwarancje ustalone w celu zapewnienia funkcjonowania określonej instytucji ${ }^{52}$. Powszechnie przyjęty ich podział wyróżnia: instytucjonalne gwarancje podmiotowo-prawne, obiektywne gwarancje instytucjonalno-prawne oraz gwarancje finansowe ${ }^{53}$.

\subsubsection{Instytucjonalna gwarancja subiektywno-prawna (Institutionelle Rechtssubjektgarantie)}

Instytucjonalne gwarancje subiektywno-prawne zapewniają gminom istnienie. Nie odnoszą się jednak do poszczególnych jednostek gminnych, ale do gminy w ogólności, pojmowanej jako podstawowa jednostka budowy systemu administracji publicznej. W literaturze przedmiotu akcentuje się pojemność tego twierdzenia, wywodząc z niego także zdolność prawną gminy oraz sprawowane przez nią władztwo terytorialne ${ }^{54}$. Innymi słowy związane jest to z zapewnieniem bytu

51 VerfG Bbg., DVB1. 1994, 857 (858), za: M. Nierhaus, op. cit., s. 118.

52 I. Schmidt, [w:] Landesrecht Brandenburg. Studienbuch, red. H. Bauer, F.J. Peine, wyd. 2, Baden-Baden 2011, s. $116 \mathrm{n}$.

53 K. Stern, Das Staatsrecht der Bundesrepublik Deutschland, t. 3/1, München 1988, s. 384 n.

54 M. Nierhaus, [w:] Grundgesetz. Kommentar, red. M. Sachs, wyd. 5, München 2009, s. 1012. 
instytucji gminy, która powinna stanowić fundament w strukturze administracji. W tym zakresie W. Thieme wskazuje na istnienie ściśle związanej ze sobą trójcy: „Federacja - Kraje Związkowe - Gminy” (Bund - Länder - Gemeinden) ${ }^{55}$.

Mimo zagwarantowania istnienia gmin, art. 28 ust. 2 zd. 1 GG nie stanowi podstawy dla ochrony poszczególnych jednostek gminnych. Stanowisko to znajduje wyraz w ustawodawstwie kraju związkowego. Artykuł 98 BbgVerf przewiduje możliwość zmiany obszaru, jak również likwidację gminy. Znajduje to potwierdzenie również $w$ dokonanych reformach terytorialnych. Prezentowany pogląd podziela również Federalny Trybunał Konstytucyjny, który orzekł, że byt gminy nie jest gwarantowany indywidualnie lecz jedynie instytucjonalnie ${ }^{56}$.

\subsubsection{Obiektywna gwarancja instytucjonalno-prawna (Objektive Rechtsinstitutionsgarantie)}

Podstawę prawną gwarancji instytucjonalno-prawnych na obszarze RFN stanowi art. 28 ust. 2 zd. 1 GG. Zgodnie z jego postanowieniami gminom musi być zagwarantowane prawo do regulowania wszystkich spraw wspólnoty lokalnej w ramach ustaw na własną odpowiedzialność. W Brandenburgii gwarancje te zostały zawarte w $\S 2$ pkt 1 BbgKVerf. Stanowi on, że gmina wypełnia na swoim obszarze wszystkie zadania wspólnoty lokalnej na własną odpowiedzialność, o ile ustawy nie stanowią inaczej. Analiza cytowanych przepisów powinna być dokonana w kontekście ich poszczególnych elementów składowych.

Pierwszy z nich to sprawy wspólnoty lokalnej. Pojęcie to nie jest zdefiniowane przez ustawodawcę. Federalny Trybunał Konstytucyjny określa je jako „te uprawnienia $\mathrm{i}$ interesy, które są zakorzenione w lokalnej wspólnocie albo mają z nią specyficzny związek, które są jako takie wspólne obywatelom gminy, dotyczą wspólnego życia i zamieszkiwania w gminie"57. W wyniku przyjęcia takiego znaczenia spraw wspólnoty lokalnej nie jest możliwe stworzenie ich zamkniętego katalogu, który w sposób autorytatywny przesądzałby naturę danego zadania. Odnosząc się do tej kwestii, Federalny Trybunał Konstytucyjny orzekł, że „do zakresu istotnego samorządności gminnej nie należy przedmiotowo oznaczony albo możliwy do sklasyfikowania według ustalonych cech katalog zadań, ale uprawnienie do przejmowania bez szczególnej kompetencji wszystkich spraw wspólnoty lokalnej, które nie zostały jeszcze przez ustawę przekazane innym podmiotom administracji publicznej"58. Pogląd ten charakteryzuje zasadę uniwersalizmu (Universalitätprinzip). Reasumując, gminie przysługuje prawo regulowania wszystkich spraw wspólnoty lokalnej, które nie zostały przekazane w drodze ustawy innym podmiotom.

55 W. Thieme, Verwaltungslehre, wyd. 4, Hamburg 1984, s. 89.

56 BVerfGE 86, 90 (107); M. Nierhaus, op. cit., s. 1012.

57 BVerfGE 79, 127 (151 n.), cyt. za: R. Stasikowski, Gwarancje samorzadności gminnej w systemie prawnym Republiki Federalnej Niemiec i Rzeczpospolitej Polskiej, Bydgoszcz 2005, s. 44.

58 Ibidem. 
Drugi element wpływający na omawiane gwarancje stanowi „odpowiedzialność własna” gminy. Odnosi się ją do „rodzaju i sposobu wykonywania zadań" ${ }^{59}$. Wynika to z faktu, że rodzaj ponoszonej przez gminę odpowiedzialności jest determinowany przez rodzaj wykonywanych przez nią zadań. Te z kolei łączą się z przyznanymi jej władztwami. Koncepcja władztw gminnych została wypracowana $\mathrm{w}$ nauce prawa. Władztwo nie jest środkiem prawnym przydającym określone prawa. Jest wyłącznie kategorią porządkującą. Władztwa są obszarami, w obrębie których gmina samodzielnie realizuje swoje uprawnienia. Wskazuje się ich poszczególne rodzaje: terytorialne, personalne, organizacyjne, statutowe, planowania, finansowe oraz kulturowe ${ }^{60}$.

W oparciu o władztwa wypracowano pogląd dotyczący tzw. swobodnej przestrzeni gmin. Stanowi ją nienaruszalna sfera, w której gminy realizują swoje suwerenne prawa. W jej obrębie gminy mogą samodzielnie regulować sprawy wspólnoty lokalnej ${ }^{61}$. Przestrzeń ta nie może zostać ograniczona. Stanowi limit dla ustawodawcy, który nie jest uprawniony do ingerowania w dowolny sposób, „W ramach ustaw”, w zadania wykonywane przez gminy. W przeciwnym razie stanowiłoby to „piętę Achillesową" gwarancji samorządności ${ }^{62}$.

Omawiając obiektywne gwarancje instytucjonalno-prawne należy zaznaczyć, że mogą one być realizowane jedynie w „ramach ustaw”. Konstrukcja art. 28 ust. 2 GG wywołuje jednak szereg wątpliwości. Z literalnego brzmienia przepisu wynika bowiem, że pojęcie ram ustawowych należałoby ograniczyć wyłącznie do zasady odpowiedzialności własnej gminy. W myśl tej koncepcji to ustawy wyznaczają granice regulowania wyłącznie tych spraw, które gmina wykonuje na własną odpowiedzialność. Takie też było początkowe stanowisko doktryny. Obecnie pojęcie to odnosi się również do elementów istotnych samorządności gmin, którymi są własna odpowiedzialność oraz zasada uniwersalizmu. Oznacza to objęcie nim nie tylko sposobu wykonania określonej sprawy, ale także faktu istnienia kompetencji gminy do realizowania określonego zadania ${ }^{63}$.

$\mathrm{W}$ ramach ustaw następuje więc regulowanie przez gminę spraw społeczności lokalnej. Ustawy wyznaczają zatem granice, w których gminy mogą samodzielnie wykonywać swoje zadania. Dominujący nurt przyjmuje wykładnię rozszerzającą pojęcia ustawy. Bezsporne jest, że należy przez nie rozumieć GG. Federalny Trybunał Konstytucyjny przyjął natomiast interpretację ,ustawy”, zgodnie z którą pojęcie to obejmuje swym zasięgiem również „ustawy federalne, rozporządzenia, ustawy krajowe, prawo zwyczajowe, podstawowe normy prawne, takie jak: plany zagospodarowania przestrzennego oraz uchwały innych wspólnot samorządowych"64.

\footnotetext{
59 I. Schmidt, op. cit., s. 117.

60 M.E. Geis, Kommunalrecht, wyd. 2, München 2011, s. 41-44.

61 I. Schmidt, op. cit., s. 119

62 Ibidem, s. 118.

63 R. Stasikowski, op. cit., s. 72 n.

64 Ibidem, s. 75.
} 
Regulacja prawna Kraju Związkowego Brandenburgii w znacznej mierze jest tożsama z rozwiązaniami ogólnymi obowiązującymi na obszarze Federacji. Rozbieżności występowały wyłącznie na płaszczyźnie interpretacji analizowanego wcześniej art. 97 BbgVerf. Trybunał Konstytucyjny Brandenburgii podzielił jednak opinię Federalnego Trybunału Konstytucyjnego odnośnie istoty omawianych gwarancji. Podkreślił także konieczność uwzględnienia w procesie interpretacji zasady proporcjonalności (Verhältnismäßigkeitprinzip) ${ }^{65}$.

\subsubsection{Subiektywna gwarancja pozycji prawnej (Subjektive Rechtsstellungsgarantie)}

Stanowi ona ochronę prawną przysługującą w przypadku naruszenia omawianych wyżej gwarancji. Przydanie gminie praw bez jednoczesnego stworzenia mechanizmów umożliwiających ich realizację mogłoby doprowadzić do faktycznej ich marginalizacji. W celu wyeliminowania potencjalnych zagrożeń ustanowiono więc subiektywne gwarancje pozycji prawnej. Są nimi przede wszystkim skargi konstytucyjne, do których wnoszenia są uprawnione poszczególne gminy ${ }^{66}$. Jest o nich mowa pośrednio w art. 93 ust. 1 pkt 4b GG. Przepis ten określa kompetencje Federalnego Trybunału Konstytucyjnego. W zakres jego orzekania wchodzi m.in. rozpatrywanie skarg konstytucyjnych wnoszonych przez gminy i związki gmin z powodu naruszenia prawa do samorządu zgodnie z przepisem art. 28 GG. Trybunał może rozpatrywać skargi konstytucyjne wnoszone przez gminy, nawet gdy zostały oparte na przepisach ustaw kraju związkowego. Może to jednak nastąpić wyłącznie w przypadku, gdy skarga nie może być wniesiona do Krajowego Trybunału Konstytucyjnego. W ten sam sposób kwestia ta jest regulowana w $§ 91$ ustawy o Federalnym Trybunale Konstytucyjnym ${ }^{67}$.

Kolejnym aktem prawnym określającym subiektywne gwarancje pozycji prawnej jest BbgVerf. Artykuł 100 przyznaje gminom oraz związkom gmin uprawnienie do wniesienia skargi konstytucyjnej wraz z uzasadnieniem, że określona ustawa kraju związkowego narusza ich prawa samorządowe zapewnione przez tę konstytucję.

Prócz omówionych wcześniej rodzajów gwarancji, wskazuje się istnienie tzw. gwarancji dodatkowych, zwanych też uzupełniającymi (Ergänzungsgarantien). W ich obrębie wyróżnia się m.in. podstawowe zasady nadzoru czy gwarancje finansowe ${ }^{68}$. Uregulowanie odnoszące się do finansów gmin stanowi, że gwarancja samorządności obejmuje także podstawę własnej odpowiedzialności

65 I. Schmidt, op. cit., s. 120.

66 M. Nierhaus, op. cit., s. 1013.

${ }^{67}$ Bundesverfassungsgerichtsgesetz in der Fassung der Bekanntmachung vom 11. August 1993 (BGBl. I s. 1473) ze zm.

68 M. Nierhaus, op. cit., s. 1024. 
finansowej. Takie brzmienie przepisu potwierdza fakt, że nie zostały one wyodrębnione jako inny typ gwarancji, lecz jedynie włączone do katalogu już istniejących. W tym zakresie wskazano także prawo gmin do pobierania podatków ze źródła odpowiadającego potencjałowi gospodarczemu w oparciu o odpowiednie przepisy. Podstawy własnej odpowiedzialności finansowej gmin zostały również określone w art. 99 BbgVerf, który stanowi, że gminy, w celu wykonywania swoich zadań, mają prawo do pozyskiwania stosownie do ustaw własnych źródeł podatków. Cytowany przepis wskazuje ponadto konieczność funkcjonowania mechanizmu kompensacji finansowej, w ramach którego gminy stosownie partycypują we wpływach podatkowych kraju związkowego.

\section{Wnioski}

Podsumowując, należy stwierdzić, że w obu porządkach prawnych będących przedmiotem badania nie wypracowano definicji legalnej samorządności gminnej. Jest ona konstruowana w oparciu o postanowienia konstytucji oraz ustaw. Szczególną rolę w tym zakresie odgrywa Europejska Karta Samorządu Lokalnego, która jest wspólną podstawą samorządności gmin w obu państwach.

Różnice występują jednak w zakresie terminologii. W polskim porządku prawnym przedmiotem ochrony jest samodzielność gmin, w niemieckim natomiast samorządność. Szczegółowa analiza przepisów wskazuje jednak, że mimo różnic terminologicznych przedmiot ochrony jest tożsamy. Jest charakteryzowany w odniesieniu do określonych instytucji prawnych, które nazywa się „gwarancjami samorządności gminnej”.

Wśród przedstawicieli niemieckiej nauki prawa panuje zgodność zarówno co do istnienia gwarancji samorządności gminnej, jak i wyodrębnienia ich konkretnych rodzajów. Są nimi: instytucjonalne gwarancje subiektywno-prawne, obiektywne gwarancje instytucjonalno-prawne oraz subiektywne gwarancje pozycji prawnej.

Brak jest natomiast zgodności poglądów reprezentowanych w polskiej literaturze przedmiotu. Możliwe jest wyodrębnienie dwóch nurtów. Pierwszy z nich nie wprowadza konstrukcji pojęciowej instytucji „gwarancji samodzielności gminnej”, uznając poszczególne instytucje prawne, takie jak: osobowość prawna gminy, samodzielność finansowa czy swoboda w zakresie określania wewnętrznego ustroju, wyłącznie prawnymi determinantami samodzielności. Drugi natomiast, charakteryzując samodzielność gminną, czyni to przez pryzmat gwarancji samodzielności gminnej, dokonując jednoczesnej charakterystyki jej poszczególnych elementów. W jego obrębie można wyróżnić dwa stanowiska: niedokonujące ich wewnętrznej klasyfikacji oraz dokonujące podziału opartego na charakterze źródeł prawa. 
W niniejszym opracowaniu została zaproponowana klasyfikacja oparta o cechy charakterystyczne wykazywane przez daną gwarancję. W oparciu o to kryterium wyodrębniono gwarancje: instytucjonalne, ustrojowe oraz finansowe. Podział posiada charakter porządkujący i ma na celu usystematyzowanie przesłanek wyróżnianych w nauce prawa.

Celem komparatystyki prawniczej jest nie tylko przedstawienie uregulowań prawnych w odmiennych systemach. Jest nim również, a może przede wszystkim, wypracowanie nowych, nieznanych dotąd rozwiązań na gruncie rodzimej nauki prawa. Czerpanie z dorobku innych kultur prawnych, często bardziej rozwiniętych, oraz korzystanie $\mathrm{z}$ tych rozwiązań przyczynia się do rozwoju istniejących już instytucji.

\section{Communal self-governance and its guaranties in the Republic of Poland and in the Brandenburg Land}

\section{Summary}

The subject of this article is the commune in the Republic of Poland and in the Brandenburg Land. A commune is a part of public administration which is based on decentralization. The legal construction of this basic entity of local government was created in view of its self-governance. The main methodology used in this work is based on the textual analysis of legal acts. The aim of the following work is to explain the conceptual meaning of communal self-governance in the aforementioned states and to analyze the comparability range of its concept. In the Brandenburg Land the concept of communal self-governance is built on the basis of self-governance guaranties. These guaranties are analyzed in detail. While in the Brandenburg Land the catalogue of these guaranties is well-known and acceptable, in the Republic of Poland it is still unclear. In order to arrange this issue, a comparable classification of self-governance guaranties in the Republic of Poland was proposed.

Keywords: self-governance, commune, local government, Republic of Poland, Brandenburg Land.

\section{Bibliografia}

Adamiak B., Borkowski J., Instytucje prawne sądowej ochrony samodzielności gminy, „Samorząd Terytorialny" 1991, nr 1-2.

Agopszowicz A., Własność komunalna - publiczna czy prywatna?, „Samorząd Terytorialny” 1991, nr 11-12.

Besonderes Verwaltungsrecht, t.3, Kommunalrecht, Haushalts- und Abgabenrecht, Ordnungsrecht,

Sozialrecht, Bildungsrecht, Recht des öffentlichen Dienstes, red. D. Ehlers, M. Fehling,

H. Pünder, wyd. 3, Heidelberg 2013.

Bigo T., Zwiąki publiczno-prawne w świetle ustawodawstwa polskiego, Warszawa 1928.

Błaś A., Konstrukcja prawna samodzielności jednostki samorządu terytorialnego, [w:] Granice sa- 
modzielności wspólnot samorządowych: Międzynarodowa Konferencja Naukowa, Baranów Sandomierski, 22-25 maja 2005, red. E. Ura, Rzeszów 2005.

Die Zukunft der kommunalen Selbstverwaltung: Vorträge und Diskussionsbeiträge der 58. Staatswissenschaftlichen Fortbildungstagung 1990 der Hochschule für Verwaltungswissenschaften Speyer, red. W. Blümel, H. Hill, Berlin 1991.

Dolnicki B., Nadzór nad samorząem terytorialnym, Katowice 1993.

Dolnicki B., Samorzad terytorialny, wyd. 5, Warszawa 2012.

Geis M.E., Kommunalrecht, wyd. 2, München 2011.

Grundgesetz. Kommentar, red. M. Sachs, wyd. 5, München 2009.

Iserzon E., Prawo administracyjne. Podstawowe instytucje, Warszawa 1968.

Jagoda J., Sądowa ochrona samodzielności jednostek samorządu terytorialnego, Warszawa 2011.

Komentarz do ustawy o samorzadzie gminnym, red. P. Chmielnicki, wyd. 3, Warszawa 2007.

Kommunale Selbstverwaltung. Beiträge zur Debatte, red. C. Büchner, J. Franzke, Berlin 1999.

Kronberger-Sokołowska E., Samodzielność finansowa jednostek samorzadu terytorialnego w aktualnym stanie prawnym w Polsce, „Studia Iuridica” 2001, nr 39.

Kuszewska-Gagoś M., Podmiotowość publicznoprawna gminy, Lublin 2009.

Landesrecht Brandenburg. Studienbuch, red. H. Bauer, F.J. Peine, wyd. 2, Baden-Baden 2011.

Leoński Z., Samorząd terytorialny w RP, Warszawa 1998.

Malinowska-Misiąg E., Misiąg W., Finanse publiczne w Polsce, wyd. 2, Warszawa 2007.

Marchaj R., Zasada samodzielności, a prawo do prowadzenia wspótpracy przez jednostki samorządu terytorialnego, [w:] Formy współdziałania jednostek samorządu terytorialnego, red. B. Dolnicki, Warszawa 2012.

Mączyński M., Samodzielność a samorządność, [w:] Nadzór nad samorządem a granice jego samodzielności, red. M. Stec, M. Mączyński, Warszawa 2011.

Miemiec M., Gmina w systemie administracji publicznej Republiki Federalnej Niemiec, Wrocław 2007.

Miemiec W., Miemiec M., Konstytucyjne gwarancje samodzielności samorząu terytorialnego, „Przegląd Prawa i Administracji” 38, 1997 („Acta Universitatis Wratislaviensis” nr 2018).

Miemiec W., Miemiec M., Podmiotowość publicznoprawna gminy, „Samorząd Terytorialny” 1991, nr $11-12$.

Miemiec W., Miemiec M., Reformowanie administracji publicznej, [w:] Między tradycją a przyszłościa w nauce prawa administracyjnego. Ksiegga jubileuszowa dedykowana Profesorowi Janowi Bociowi, red. J. Supernat, Wrocław 2009.

Miemiec W., Sawicka K., Miemiec M., Prawo finansów publicznych sektora samorządowego, Warszawa 2013.

Milczarek T., Samorząd gminny, Warszawa 1999.

Niewiadomski Z., Samorząd terytorialny. Ustrój i gospodarka, Bydgoszcz 2011.

Ochendowski E., Prawo administracyjne. Część ogólna, Torun 2004.

Panejko J., Geneza i podstawy samorzadu europejskiego, Paryż 1926 (reprint Warszawa 1990).

Peters H., Lehrbuch der Verwaltung, Berlin 1949.

Podmioty administrujace, Warszawa 2011, („System Prawa Administracyjnego”, red. R. Hauser, Z. Niewiadomski, A. Wróbel, t. 6).

Prawo administracyjne, red. M. Wierzbowski, wyd. 10, Warszawa 2011.

Prawo administracyjne, red. M. Wierzbowski, wyd. 11, Warszawa 2013.

Prawo finansowe, red. R. Mastalski, E. Fojcik-Mastalska, wyd. 2, Warszawa 2013.

Raadschelders J.C.N., Centralizacja i decentralizacja: dychotomia i kontinuum, „Samorząd Terytorialny" 1994, nr 6.

Rajca L., Konstrukcja osobowości prawnej samorząu terytorialnego, „Samorząd Terytorialny” 2004, nr 3. 
Stasikowski R., Gwarancje samorządności gminnej w systemie prawnym Republiki Federalnej Niemiec i Rzeczpospolitej Polskiej, Bydgoszcz 2005.

Stern K., Das Staatsrecht der Bundesrepublik Deutschland, t. 3/1, München 1988.

Thieme W., Verwaltungslehre, wyd. 4, Hamburg 1984.

Ura E., Ura E., Prawo administracyjne, Warszawa 2009.

Zimmermann J., Prawo administracyjne, wyd. 4, Warszawa 2010.

Zimmermann J., Prawo administracyjne, wyd. 5, Warszawa 2012.

\section{Wykaz aktów prawnych}

Bundesverfassungsgerichtsgesetz in der Fassung der Bekanntmachung vom 11. August 1993 (BGBl. I s. 1473) ze zm.

Europejska Karta Samorządu Lokalnego z dnia 15 października 1985 r., Dz.U. z 1994 r. Nr 124, poz. $607 \mathrm{ze} \mathrm{zm}$.

Grundgesetz für die Bundesrepublik Deutschland vom. 23 Mai 1949 (BGB1. S. 1), zuletzt geändert durch das Gesetz vom 11. Juli 2012 (BGBl. I S. 1478).

Kommunalverfassung des Landes Brandenburg vom 18. Dezember 2007 (GVB1. I/07, [Nr. 19], s. 286), zuletzt geändert durch Artikel 4 des Gesetzes vom 10. Juli 2014 (GVBl. I/14, [Nr. 32]).

Ustawa z dnia 23 kwietnia 1964 r. — Kodeks cywilny, tekst jed. Dz.U. z 2014 r., poz. 121 ze zm.

Konstytucja Rzeczypospolitej Polskiej z dnia 2 kwietnia 1997 r., Dz.U. Nr 78, poz. 483 ze zm.

Ustawa z dnia 8 marca 1990 r. o samorządzie gminnym, tekst jedn. Dz.U. z 2015 r., poz. 1515 ze zm. Verfassung des Landes Brandenburg vom 20. August 1992 (GVB1. I/92, [Nr.18], s.298), zuletzt geändert durch Gesetz vom 05. Dezember 2013 (GVBl. I/13, [Nr. 42]).

\section{Wykaz stron internetowych}

www.sjp.pwn.pl/slownik/2519152

www.wuwr.com.pl/onelinetexts/download/37.html

Prawo 320, 2016

(C) for this edition by CNS 